\title{
Depresioaren teoria neuroinflamatorioa
}

\author{
Neuroinflammatory theory of depression \\ Lierni Goitia ${ }^{1}$ eta Igor Horrillo ${ }^{2,3,4}$ \\ ${ }^{1}$ Hospital Universitario de Gran Canaria Dr. Negrín (HUGC Dr. Negrín) \\ ${ }^{2}$ Farmakologia Saila, Euskal Herriko Unibertsitatea, UPV/EHU \\ ${ }^{3}$ Centro de Investigaciones Biomédicas en Red de Salud Mental (CIBERSAM) \\ 4Biocruces Osasun Ikerketa Institutua \\ igor.horrillo@ehu.eus
}

\section{Laburpena}

Depresio nagusia asaldura neuropsikiatriko ohikoenen artean dago. Gaixotasun mental honen etiologia eta oinarri fisiopatologikoak azaltzeko hainbat teoria proposatu dira, hala nola teoria monoaminergikoa edo neurotrofikoa. Hala ere, oinarri neurobiologikoak oraindik ez dira ezagutzen, sistema ezberdinen parte-hartzea izanik proposatzen dena.

Depresioan hanturaren eta funtzio neuralaren arteko elkarrekintza dagoela frogatzen duten entsegu prekliniko eta klinikoetako emaitzak gero eta pisu handiagoa hartzen ari dira, teoria neuroinflamatorioa indartuz. Horrek proposatzen du depresioan sistema ezberdinetan asaldurak gertatuko liratekeela: ardatz hipotalamiko-hipofisiario-adrenalaren (HPA) hiperaktibazioa (igotako glukokortikoide-mailak eraginez) bai eta sistema immunearen hiperaktibazioa ere, periferiako eta nerbio-sistema zentraleko (NSZ) hanturaren markatzaileen, hau da, zitokina proinflamatorioen mailak handituz. Gainera, depresiodun pazienteetan aurkitu diren periferiako gehiegizko zitokinak garunera igarotzeko gai direla eta depresioan ezagunak diren bide fisiopatologiko gehienei eragiten dietela deskribatu da. Horien artean neurotransmisoreen metabolismoa, funtzio neuroendokrinoa eta plastikotasun edo moldatze neurala daude. Hain zuzen ere, garuneko hanturaren aktibazioak depresioan gertatzen diren asaldura fisiopatologikoen antzeko moldaketak eragiten ditu, faktore neurotrofikoen gutxipena, eszitotoxikotasuna eta horren ondorio den estres oxidatiboa, adibidez. Areagotutako zitokinen kalte kronikoak iraupen luzeko aldaketak dakartza garunaren anatomian eta funtzionamenduan, eta kalteok umorean, kognizioan edo portaeran eragin zuzena izango dute.

Hortaz, garunaren endekapen hau sintoma depresiboekin lotzea funtsezkoa da tratamendua aukeratzeko orduan. Izan ere, gaixotasun inflamatorioak dituzten pazienteetan lortutako emaitzen arabera, zitokina proinflamatorioak inhibitzeak gaixoek pairatzen dituzten sintoma depresiboak hobetzen eta pazientearen ohiko tratamendu antidepresiboaren erantzuna hobetzen lagundu dezake. Beraz, garunean gertatzen den hantura eta sistema immunea itu dituzten tratamenduak garatzea aukera bat izan daiteke hantura duten depresiodun pazienteen sintomatologia hobetzeko.

Gako-hitzak: depresioa, neuroinflamazioa, mikroglia, zitokina 


\section{Abstract}

Major depressive disorder is becoming one of the most prevalent neuropsychiatric disorders. Although the etiology or neurobiological bases are unknown, several theories have been proposed such as the monoaminergic or neurotrophic theories. Preclinical and clinical studies showing interaction between inflammation and neural function in depression are becoming increasingly important, supporting the neuro-inflammatory theory. In this regard, depressive disorders have been shown to be related to hypothalamic-hypophysial-adrenal (HPA) hyperactivity (resulting in an elevated glucocorticoid levels) and also a hyperactive immune response. Elevated concentrations of inflammatory markers, such as pro-inflammatory cytokines, have been reported in the central and peripheral nervous systems of depressive patients. Additionally, peripheral cytokines are able to reach the brain and affect most pathophysiological pathways related to depression. These include neurotransmitter metabolism, neuroendocrine function, and neural plasticity or adaptation. Furthermore, brain inflammation is able to induce pathophysiological adaptations similar to those which occur during depression, including reduction of neurotrophic factors, steroidal toxicity and the resulting oxidative stress. Chronic damage caused by cytokines leads to long-term changes in brain anatomy and functioning, consequently affecting mood, cognition and/or behavior. In fact, results obtained in patients with inflammatory diseases suggest that reduced levels of proinflammatory cytokines could help to improve depressive symptoms and may even enhance the response to conventional antidepressant treatments. Therefore, the development of treatments targeting brain inflammation and immune response may be an opportunity to improve the symptomatology of depressed patients.

Keywords: depression, neuroinflammation, microglia, cytokines

Bidalia: 2017ko urriaren 6an.

http://doi.org/10.26876/osagaiz.1.2018.100

Onartua: 2018ko apirilaren 6an.

\section{Sarrera}

Depresioa emozioen erregulazioan eragiten duen asaldurarik ohikoena da, munduan 350 milioi pertsona baino gehiago gaixotzen dituena, emakumezkoetan gizonezkoetan baino prebalentzia altuagoa duelarik (1).

Gaitz afektibo bat da, baina anhedonia (plazera sentitzeko ezgaitasuna), tristura eta egoera emozional baxua bezalako sintoma afektiboez gain, ikusmen espazialeko arretan, oroimenean, exekuzio-funtzioetan eta beste funtzio kognitibo batzuetan ere desorekak agertzen dituzte deprimituek. Horregatik, asaldura mental honek ondorio negatibo ugari dakartza gaixoen bizitzara: alde batetik, sufrimendu eta sintoma latzak, kasurik okerrenetan heriotzara daramatenak, suizidioa dela-eta, eta, bestetik, ezgaitasuna eragiten duen lehenengo kausa globala da eta modu garrantzitsuan gehitzen du morbilitate-karga orokorra $(1,2)$.

Hauek dira asaldura depresibo nagusian agertzen diren sintoma adierazgarrienak (3):

- Pisu-igoera edo -galera esanguratsua.

- Anhedonia, edo atsegina den edozein sentsazio sentitzeko ezintasuna.

- Gogo-aldarte narritakorra edo depresiboa.

- Loezintasuna edo gehiegizko loa.

- Agitazio edo geldotze psikomotorra.

- Energia-galeraren sentsazioa edo nekea.

- Gutxiespen- eta erruduntasun-sentimenduak.

- Pentsatzeko edo kontzentratzeko zailtasuna.

- Heriotza edo suizidioaren inguruko pentsamendu errepikakorrak. 
- Estresa gaizki jasatea: egunerokotasuneko arazo txikiak onartzeko eta konpontzeko zailtasuna.

Depresiorako tratamendu eraginkorrak dauden arren (psikoterapia eta farmakoak), gaitza diagnostikatzeko orduan zailtasunak daude. Izan ere, tristura gizakiari lotuta doan egoera naturala da eta horren maila ebaluatzea ez da erraza. Ez da aurkitu diagnostikorako metodo egokirik ezta ebaluazio kliniko zehatzik ere, baina Gaixotasun Mentalen Amerikar Elkarteak, Gaixotasun Mentalen Diagnostikorako eta Estatistikarako Eskuliburuari (DSM-V) esker, eta diagnostikorako hain garrantzitsuak diren galdeketa klinikoen ondoren, depresioaren sailkapena egitea lortu zuen (4). Egun erabilienak diren galdeketak Hamilton eskala, Montgomery-Asberg galdeketa eta Beck galdeketa dira, bakoitzak depresioaren ikuspegi ezberdina neurtzen duelarik. Galdeketa horietaz gain, aurrekari familiarrak eta gaixotasunaren eboluzioa ere kontuan izaten dira, besteak beste. Hortaz, galdeketa kliniko on bat egitea izango litzateke, egun, diagnostiko egokia egiteko lanabes nagusia.

Gaixotasunaren etiologiari dagokionez, oraindik ezezaguna den arren, ikerketa askok adierazten dute faktore genetikoen, faktore psikosozialen eta neurotransmisioaren eta maila hormonalen asalduren konbinazioak depresioa eragin dezakeela (3). Depresio endogenoaren etiologia eta fisiopatologia argitzen jarraitzeko asmoz, azken urteetan hainbat hipotesi garatu dira, non gaixotasuna ikuspuntu ezberdinetatik aztertu den, eta horietatik aipagarrienak teoria monoaminergikoa eta teoria neurotrofikoa dira.

\subsection{Depresioaren etiopatogeniaren lehen proposamena: teoria monoaminergikoa}

Hau izan zen lehenengo proposatu zen hipotesia tratamendu farmakologiko eraginkorraren ekintzamekanismoa aztertu ostean. 50eko hamarkadan antituberkuloso gisa garatu zen iproniazida farmakoak aktibitate antidepresiboa zuela aurkitzeak ireki zion hipotesiari bidea. Teoria honek depresio endogenoaren etiopatogenia nerbio-sistema zentralean gertatzen den aktibitate monoaminergikoaren (noradrenergikoa edota serotonergikoa) gutxitzearekin erlazionatzen du. $\mathrm{Bi}$ neurotransmisoreen sinapsietan, bai maila presinaptikoan bai maila postsinaptikoan, gertatzen diren hainbat mekanismoren asalduren ondorioz, tarte sinaptikoan erabilgarri dagoen noradrenalina edo/eta serotonina kantitatea murriztua egongo litzateke (1. irudia); horrela, bi sistemen funtzioa kaltetuz eta horiekin erlazionatutako garuneko beste zati batzuetan ere eragina izanez, hala nola hipokanpoan (oroimenarekin erlazionatua), garunaren aurreko kortexean (PFC) (egoera animikoarekin erlazionatua), hipotalamoan (gosearen eta oroimenaren erregulatzailea) eta amigdalan (beldurraren eta antsietatearen prozesuekin erlazionatua).

Monoaminen gutxipena proposatzen duen hipotesia frogatzen dute depresiodun pazienteetan egin diren aurkikuntzetariko batzuek, adibidez (1. irudia): depresioan berrerortzea dakarrela noradrenalina katalizatzen duen tirosin hidroxilasa entzimaren inhibizioak edo dietatik noradrenalinaren aitzindari den tirosina kentzeak. Bestalde, depresioarekin erlazionatu dira ere presinaptikoki monoaminak katalizatzen dituen A monoamino oxidasa (MAO-A) entzimaren aktibitatea areagotzea eragingo lukeen ligando espezifikoaren loturan igoera bat, neurotransmisoreen seinaleen aurrean, G proteinetara lotutako monoaminen hartzaile postsinaptikoen erantzun desegoki bat (5), etab.

Hainbat ikerlanek beste ikuspuntu batetik aztertzen dute teoria hau. Neurotransmisoreen sistemen desorekaz gain, haien hartzaileen erregulazioaren desoreka bat ere proposatzen dute. Adibidez, noradrenalinak (NA) bere jariapena kontrolatzen du berak eragiten duen feedback mekanismoaren bitartez. Mintz presinaptikoan transmisioa erregulatzeko $\alpha_{2}$ adrenohartzaileak daude: horiek neurotransmisorearen askapenaren inhibizioa eragiten dute neurona presinaptikoan. Ikerketa batzuen arabera, depresioa duten gaixoengan (garun zein plaketetan) $\alpha_{2}$ hartzaileen kopurua handituta dago, beraz, NAren askapenaren inhibizioa ere handitu egingo litzateke. Ondorioz, tarte sinaptikoan noradrenalina gutxiago egongo litzatekeela pentsa dezakegu (errebisio gisa begiratu 4. erreferentzia). Berdina gertatuko litzateke serotoninaren $\mathrm{A} 1$ autohartzaile inhibitzailearekin $\left(5-\mathrm{HT}_{1 \mathrm{~A}}\right)$, hau da, depresioan horren kopurua ere handituta dagoela ikusi denez, serotoninaren askapena 
gutxituko litzateke eta tarte sinaptikoan neurotransmisore gutxiago egongo lirateke. Gainera, antidepresiboekin hartzaile monoaminergiko inhibitzaileen desentsibilizazioa gertatzen dela frogatu $\mathrm{da}$, beraz, aurkikuntza horrek hartzaile horien zenbatekoaren igoeraren teoria indartuko luke (6).

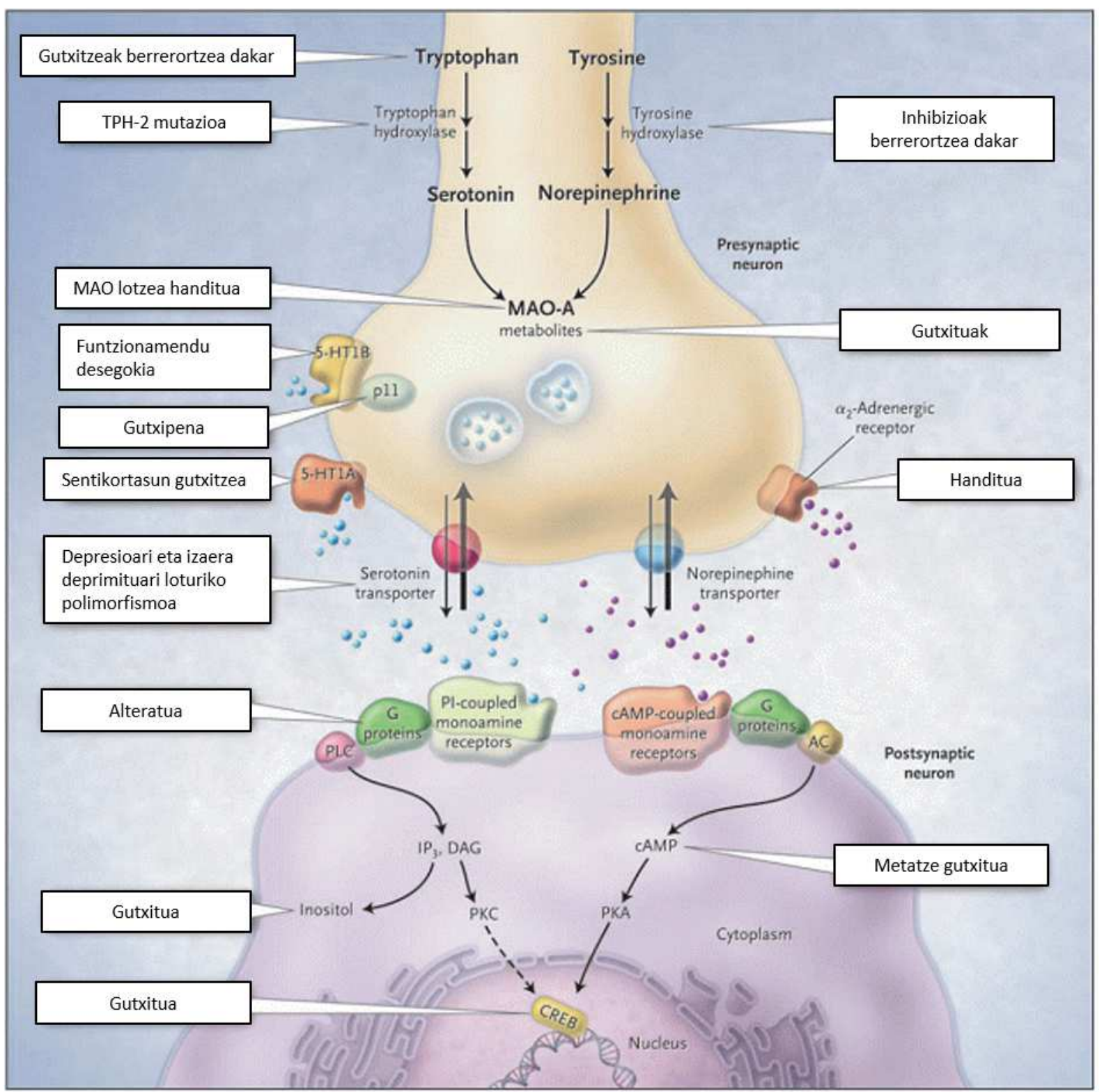

1. irudia. Hipotesi monoaminergikoaren azalpen grafikoa. Belmaker R eta Agam G. Major Depressive Disorder.New England Journal of Medicine. 2008;358(1):55-68 (moldatua).

Teoria monoaminergikoa urte askotan zehar depresioaren teoria nagusia izan den arren, gaitzaren etiopatogenia soilik neurotransmisioan ematen diren alterazioen ondorioz gertatzen dela pentsatzea sinpleegia dela onartu dute adituek. Denboran zehar egin diren aurkikuntza berriei esker (adibidez, depresioak jotako gaixo askoren garun zatietako aldaketa morfofuntzionalak), egun gaixotasuna era zabalago batean aztertzen da, hipotesi gehiago proposatzeari bidea emanez.

\subsection{Depresioaren hipotesi neurotrofikoa}

Proposaturiko teoria horien artean garrantzitsuena90eko hamarkadan deskribatutako hau izan daiteke. Izenak faktore neurotrofikoei egiten die erreferentzia. Faktore horiek garuneko zelulek askatzen dituzte, eta neuronen eta glia zelulen (neuronen euskarri funtzioa duten eta informazioaren prozesamenduan laguntzen duten NSZko zelulak) garapena, biziraupena eta plastikotasuna erregulatzen dituzten egitura proteikoak dira. Hipotesi honen proposamen nagusiak dio depresioan 
faktore neurotrofikoen mailak gutxitu egiten direla eta, ondorioz, garunaren zenbait atalen endekapena gertatzen dela, alterazio morfofuntzionalak eraginez (errebisio gisa begiratu 4. erreferentzia). Adibidez, depresioan hipokanpoaren bolumenaren murrizketa, PFCaren gune batzuen bolumenaren murrizketa, amigdalaren bolumenean aldaketak, etab. ikusi dira, gune horiek bide linbiko-kortiko-talamikoaren osagai direlarik, prozesamendu emozional eta kognitiboarenerantzuleak izanik. Gainera, tratamendu antidepresiboak hipokanpoaren bolumenaren galera saihestu dezakeela deskribatu da bai eta depresio mota eta larritasunaren araberako eragin babesgarria duela ere.

Depresioa bezalako gogo-aldartearen asaldurekin gehien erlazionatu den faktore neurotrofikoa garunetik eratorritako faktore neurotrofikoa (BDNF) deiturikoa da, plastikotasun neural eta neurogenesiaren erregulaziorako ezinbestekoa dena. Tirosin kinasa erako bere hartzaileari lotuz, TrkB delakoa, hainbat seinalizazio-bide bultzatu eta neuronen dendriten arborizazioa kontrolatzen $\mathrm{du}$, esate baterako (3). Estresak eta kortisolak neuronen biziraupenerako eta sinapsien egokitasunerako hain garrantzitsua den BDNFaren mailei eragiten dietela deskribatu da. Suizidatutako depresiodun pazienteetan eginiko post-mortem azterketa batean, murriztutako BDNF mailak erakutsi zituzte hipokanpoan. Gainera, farmako antidepresiboekin eta terapia elektrokonbultsiboarekin BDNF mailak igotzen direla ikusi da. Hortaz, BDNFa depresioan azaltzendiren estres, neurogenesi eta hipokanpoko atrofia prozesuak lotzen dituen faktorea dela ondoriozta daiteke (5).

Aipatu bezala, areagotutako glukokortikoide-mailek neurogenesia gutxitu dezaketela frogatu da, eta horien administrazioa denboran zehar luzatuz gero, heriotza zelularra ere eragin dezaketela ikusi da. Adibidez, glukokortikoideekin tratatutako karraskarien garunetan atrofiaren aldaketak deskribatu dira. Neurogenesiaren gutxipena hipokanpoaren bolumen-murrizketaren mekanismo posible bat izan litekeela ere proposatu da $(5,7)$.

Bestalde, funtzio immunearen eta neuralaren arteko erlazioaren inguruan azken urteetan egin diren aurkikuntzek depresioaren etiopatogenia ikasteko bide berri bat zabaldu dute, neuroinflamazioaren teoria planteatzearekin batera (8). Hipotesi horrek gaitzaren ikuspegi sistemikoago bat lantzen du, baina garunean gertatzen diren eta depresioa garatzeko beharrezkoak izango liratekeen mekanismo neuroimmuneei garrantzi nagusia emanez. Hasteko, ardatz hipotalamiko-hipofisiario-adrenalaren (HPA)hiperaktibazioak ardatz neuroendokrino honen osagaien jariapena areagotuta egotea eragingo luke, zirkulaziora gehiegizko kortisol glukokortikoidea askatuz (2. irudia). Horretaz gain, kortisolaren bidezko feedback negatibo murriztua legoke, ardatzaren hiperaktibazioa indartuz. Feedback mekanismoen disfuntzioa hartzaile glukokortikoideen desentsibilizazio posible batengatik gertatuko litzateke, haien funtzioa galtzea eragingo lukeena, adibidez, neurotransmisio monoaminergikoa kaltetuz. Bestalde, kortisolak sistema immunea inhibitzeko eragiten duen feedback negatiboa ere hondatuta legoke, zitokinak bezalako hantura-faktoreen jariapena igoz. Horiek nerbio-sistema zentralera igaro eta HPAardatza aktibatuko lukete, inflamazio-prozesua kronifikatuz. Gainera, zitokinek zuzenean eragingo lukete kaltea neuronetan eta haien komunikazioetan, garunaren funtzionamendu egokia oztopatuz.

\subsection{Ardatz hipotalamiko-hipofisiario-adrenala}

HPA ardatza organismoak estresari erantzun fisiologiko adaptatiboa emateko duen bide nagusia da. Haren osagaiak hauek dira: hipotalamoko nukleo parabentrikularra (PVN), hipofisiko zelula kortikotropoak eta giltzurrun gaineko guruinaren azala. Aipatutako hiru egitura horiek kortikotropinaren faktore askatzailea (CRF), kortikotropina (ACTH) eta glukokortikoideak (GC) sintetizatu eta askatzen dituzte, hurrenez hurren. Ardatz horrek, beraz, glukokortikoideen sintesia kontrolatzen du, hiru guneen arteko elkarreragite eta ardatzaren feedback negatiboaren bidez; hau $\mathrm{da}$, sistemak seinalea inhibitzeko gaitasuna du, horrela, oreka fisiologikoa edo homeostasia mantenduz. Ondorioz, estresari erantzuna ematean (homeostasia alda dezakeen edozein estimulu fisiko edo psikologikoren aurrean), helburu nagusia oreka fisiologikoa modu azkar eta eraginkorrean berreskuratzea izango da. Horretarako, organismoak hainbat mekanismo martxan jarriko ditu, 
adibidez, lehenik eta behin, nerbio-sistema sinpatikoaren (NSS) aktibazio azkarra, arreta areagotu eta organismoa arrisku-egoera baterako prestatzeko, behar ez diren portaera guztiak inhibituz, eta, ondoren, HPA ardatzaren aktibazioa, glukokortikoide-mailak igoarazteko (9).

Azken 40 urteetan egin diren ikerketen arabera, depresioaren ezaugarri sendoenetariko bi HPA ardatzaren feedback negatiboaren erregulazioaren desoreka eta kortisolaren hiperjariapena dira (10). Feedback horren bidez gertatzen den glukokortikoideen bidezko ardatzaren inhibizioa gutxitua dagoela proposatu da, beraz, HPA ardatza hiperaktibatua legoke (11).

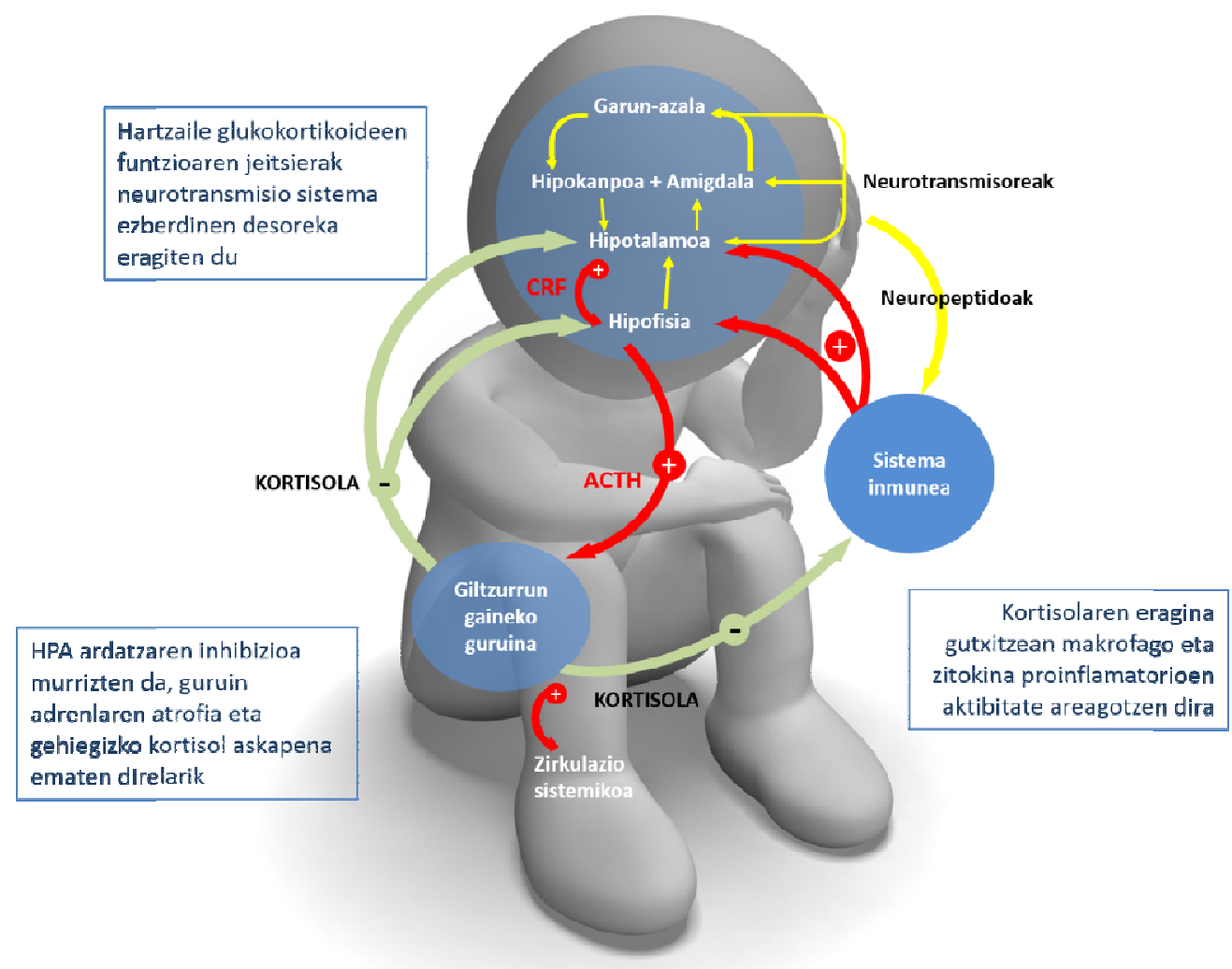

2.irudia. Teoria neuroinflamatorioaren azalpen orokorra, proposatzen dituen funtsezko alterazioak laburtzen dituena.

HPA ardatzaren kontrola hartzaile intrazelular batzuek, bereziki, hartzaile glukokortikoideek (GR), daramate. Horregatik, paziente deprimituetan GRen zenbatekoa eta/edo funtzioa gutxitua egon daitekeela proposatu dute hainbat ikerketak. Horretaz gain, beste ikerketa batzuek antidepresiboak GR mailak igotzeko gai direla ikusi dute, glukokortikoideen funtzioa berreskuratuz $(12,13)$.

Glukokortikoideen hartzaileak, aipatu bezala, zelula barneko hartzaileak dira. Behin haien ligandoei lotuta,transkripzio-faktore moduan aritzen dira, gene-espresioa kontrolatuz; hau da, promotor geniko induktore edo inhibitzaileen gain eragiten dute eta haien gisa ere aritzen dira. GRek glukokortikoideekiko afinitatea dute soilik, eta egoera fisiologiko normaletan partzialki beteta daude. Beraz, GC maila altuak behar dira (adibidez, estresak eragindakoak) hartzaile horiek guztiz aktibatzeko. Funtzio nagusia estresak eragindako aktibazio neural eta endokrinoa gelditu eta horren aurreko jokabide-erantzunak erregulatzea da. Adibidez, GC kontzentrazio altuen aurrean, hartzaileen espresioa gutxitu egingo da, moldatze-mekanismo gisa (9).

Glukokortikoide nagusia gizakietan kortisola edo hidrokortisona da, eta guruin adrenalaren azalaren zati faszikulatuan ekoizten da. Estres-estimuluei eta glukokortikoide-maila plasmatiko baxuei erantzuteko askatzen da, bere sintesi propioa erregulatzeko gai delarik. Hainbat funtzio betetzen dituzte organismoan glukokortikoideek, hala nola estresaren erantzunaren kontrola, gluzido, lipido 
eta proteinen metabolismoaren kontrola eta sistema immunearen inhibizioa (ezaugarri antiinflamatorio eta immunogutxitzaileak dituzte) (9).

Asko dira gizakietan kortisol-mailaren igoeraren eta depresioaren arteko erlazioa aztertu duten ikerketak. Horietako batek, adibidez, asaldura depresibo nagusia duten pazienteek plasman, gernuan eta likido zefalorrakideoan (LZR) kortisol-maila handituak azaltzen dituztela aurkitu zuen (16).Izan ere, jakina da depresioa pairatzen duten pertsonen erdiek, gutxi gorabehera, hiperkortisolemia dutela, tratamendu antidepresiboarekin itzulgarria dena; eta are gehiago, hiperkortisolemia kroniko batetik bereizten den gaixotasuna, hau da, Cushing sindromea, duten gaixoetan ere depresio-tasa altuak agertzen direla ikusi da. Horretaz gain, eta tratamenduari dagokionez, depresioan erabiltzen diren hainbat farmako antidepresibo eraginkorrek kortisola erregulatzen duten substratu neuroendokrinoetan jarduten dute. Emaitza hauek adierazten dute depresioaren zenbait alderdi HPA ardatz desorekatu batek sor ditzakeela (7). Depresiodun gaixoetan meta-analisi bidez eginiko ikasketa batean, tratamendua jaso aurreko eta ondorengo kortisol-mailak neurtu ziren. Partaide deprimituen \% 56k antzeko kortisol-mailak izan zituen tratamendua jaso aurretik eta ondoren (17). Horren arabera, kortisol-maila altuak depresiodun pazienteen azpimultzo batekin bakarrik egongo lirateke lotuta, eta ebidentzia gehiago behar den arren, tratamenduaren eraginkortasuna neurtzeko markatzaile potentzial bezala erabil litezke.

Nahiz eta estres kronikoaren eta depresioaren arteko lotura frogatzen duen ebidentzi kliniko zabala egon, oraindik ezezaguna da depresiodun gaixoetan ikusi diren kortisol-maila altuek gaitza eragiten duten ala gaitzaren ondoriozko produktuak diren. Hori dela-eta, garrantzitsua da HPA ardatzaren hiperaktibitate eta/edo kortisol-maila altuek depresioa eragin dezaketen jakitea, eta hala izatekotan, zer mekanismoren bidez gertatzen den. Horren harira, azken urteetan glukokortikoideen kontzentrazio altuek gaixo deprimituen sistema immunean eragin ditzaketen asalduretara begira daude zientzialariak. Izan ere, gaixo horiek immunoaktibazioa pairatzen dutela proposatu da.

\section{Non da gaixoen sistema immunologikoa?}

Sistema immunea osasuna arriskuan jar dezaketen agenteei aurre egiteko organismoak duen defentsa-mekanismoen sistema da. Defentsa-mekanismo horiek berezkoak edo hartutakoak ala adaptatiboak izan daitezke. Berezko defentsa-mekanismoen barnean berezko erantzun immunea dago, bi prozesu nagusi barne hartzen dituena: hantura edo inflamazioa eta fagozitosia.

Hantura kaltearen aurkako erantzun fisiologiko arrunta da, bai kalte mekanikoaren baita infekziosoaren aurka ere. Hasieran erantzuna leku batera mugatua dago, baina beranduago erantzun sistemikoa gara daiteke. Berehala martxan jartzen den erantzun inespezifikoa da, zauriaren gunean gorritasuna, edema, berotasuna eta mina eraginez. Prozesu inflamatorio guztietan ematen da odoletik datozen makrofagoen aktibazioa eta leukozito edo zelula immuneen barneratzea. Makrofagoek hantura-eragileak diren substantziak askatzen dituzte, infekzio-gunera molekula eta zelula efektore gehiago erakartzeko asmoz. Hantura-eragileak diren substantzien artean zitokinak daude. Zitokinak pisu molekular baxuko proteinak dira, estimulu baten aurrean modu iragankorrean ekoitzi eta jariatzen direnak, hortaz, zelulen komunikazioaren bitartekariak dira. Zitokinek inguruan gertatzen denaren berri ematen diete zelulei, berauek erantzun egokia sortzeko. Prozesu askotan parte hartzen dute, hantura-erantzunaz eta berezko eta hartutako erantzun immuneaz gain (18). Zitokina horien artean daude tumoreen nekrosiaren alfa faktorea (TNF- $\alpha$ ), interferoia (IFN) edo interleukinak (IL-1, IL-2...), adibidez.

Depresioan immunoaktibazioa gertatzen dela aurkitzeak zitokinak aztertzera garamatza. Horrela, zitokinen kontzentrazioa igotzeak gaixotasunaren agerpenean eragina izan dezakeela proposatu da, depresioaren modulatzaile bezala jokatuz. Hori horrela dela pentsatzeko hainbat arrazoi daude. Hasteko, depresioa IL-1 $\beta$, IL-6, TNF- $\alpha$ eta IFN- $\gamma$ bezalako zitokina proinflamatorioen ekoizpenaren igoerarekin erlazionatuta dagoela ikusi da deprimitutako gaixoetan eginiko meta-analisi azterketetan (8). Bestalde, ehun-kalteagatik, infekzioagatik edo gaixotasun autoimmune edo neoplasikoagatik 
hantura edo immunoaktibazioa duten pertsonek depresioaren prebalentzia-tasa altuak erakusten dituztela frogatu da. Azkenik, minbizia eta gaixotasun infekziosoak tratatzeko erabiltzen diren zitokina bidezko terapiak ere ezagunak dira, eragin ditzaketen portaera-asaldurengatik (10).

Asko dira depresioan hanturak duen papera indartzen duten datuak. Depresio nagusidun pazienteek erantzun inflamatorio baten ezaugarri guztiak erakusten dituzte odol periferikoan eta LZRan, hala nola zitokina proinflamatorioen eta haien hartzaileen espresioaren igoera, fase akutuko erreaktiboen mailen igoera edo atxikipen-molekula disolbagarrien mailen igoera. Literaturako meta-analisien arabera, depresiodun pazienteetan, odol periferikoan IL-1 $\beta$, IL-6, TNF eta C proteina erreaktiboa (CRP) (hantura-mailaren adierazle goiztiarra) hanturaren biomarkatzaile fidagarrienak direla ondorioztatu daiteke (19). Depresiodun pazienteek estres psikologiko akutuaren ondoriozko gehiegizko erantzun inflamatorio bat ere erakusten dute, IL-6-aren igoera eta jauzi inflamatorioa seinalizatzen duen transkripzio-faktorearen (NF-kB) aktibazioarekin batera. Horretaz gain, zirkulazioan dauden beste faktore proinflamatorio batzuen igoerak ere deskribatu dira, TNF- $\alpha$, IL-1 edo IL-12 (makrofagoek jariatutako hanturaren hasierako faseetan eragiten duen interleukina), besteak beste (10).

Nekea, disfuntzio kognitiboa edo loaren asaldurak bezalako sintoma depresiboen eta hanturaren markatzaileen arteko loturak ere ezarri dira. Adibidez, paziente deprimituetan agertzen den loaren desoreka IL-6-aren igoerekin eta NF-kB-ren aktibazioarekin lotu da.

Sintoma depresiboak eta hanturaren markatzaileak elkar lotzen dituzten datuez gain, zitokinen administrazio akutu eta kronikoek (edo zitokinak induzitzen dituzten substantzienak: lipopolisakaridoa edo txertaketa, esate baterako) depresio nagusian ematen diren portaera-sintomen baliokideak eragiten dituztela frogatzen dute. Adibidez, boluntario osasuntsuek lipopolisakaridoa (bakterioen mintzetik ateratako polimeroa) injektatuz gero, antsietate- eta depresio-sintomen igoera akutuak pairatzen dituzte. Esan bezala, denbora luzean zehar zitokinak administratuz gero, portaeraasaldura nabarmenak eragiten dira gizakietan. Horren froga da minbizia edo gaixotasun infekzioso bat pairatzen duten gaixoak tratatzeko interferoi-alfaren (IFN- $\alpha$ ) administrazio kronikoa jasaten duten pertsonen \% 20-50ek klinikoki esanguratsua den depresioa garatzen duela (20). Zehazki, IFN- $\alpha$ arekin tratamenduan zeuden hepatitis C-dun gaixoetan eginiko azterketa batean, \% 40k DSM-V-ren arabera sailkatutako depresio nagusia pairatu zuela deskribatu zen (21).

Sistema immunea ardatz neuroendokrinoaren osagaien jariapenean aldaketak eragiteko gai da, HPA ardatza hiperaktibatzea eraginez. Horregatik, eta depresioarekin duen erlazioa argitu nahian, ikerketa asko egin dira sistema immune eta HPA ardatzaren inguruan. Horietako batek IFN- $\alpha$-arekin tratamenduan zeuden minbizidun paziente batzuei zitokina hori administratzeak HPA ardatzean izan lezakeen eragina ikasi zuen, tratamenduak iraun bitartean depresioa garatzeko arriskua neurtzeko. Horretarako, interferoi-alfa (IFN- $\alpha$ ) tratamendua jaso ostean, ACTH, kortisol eta interleukina-6 (IL-6) zitokina proinflamatorioa neurtu zitzaien odolean minbizidun hamalau gaixori, eta, besteak beste, depresioaren sintomak agertzen ziren. Sintoma depresiboak izan zituzten pazienteetan ACTH eta kortisol-mailen igoera esanguratsuagoa (IL-6-arena ez) eman zen sintomarik izan ez zutenekin konparatuz, modu akutuan. Beraz, IFN- $\alpha$ administrazio akutuaren ondorioz sortutako HPA ardatzaren erantzunaren igoera tratamenduaren ondoriozko depresioa garatzearen erantzulea izan daiteke (22). Zitokina proinflamatorioen administrazioak CRFaren jariapena igotzeko gaitasuna duen ere ikasi da. Zitokinak, era akutuan administratuta, CRFaren espresioa eta sintesia handitzeko gai direla frogatu dute, baita ACTH eta kortisolarena ere, horien guztien mailak igoaz depresiodun pazienteetan (23).

Animalietan eginiko ikerketei dagokienez, zitokinaren tratamenduak sintoma depresiboak eragin diezazkiekeela ikusi da. Horretarako, zitokinen bidezko depresioaren animalia-eredua sortu zen, animaliei hantura induzituz. Zitokinaren administrazio exogenoaren bidez, sistema immune periferikoa estimulatzea lortzen da, gehiegizko erantzun neuroinflamatorioa eta sintoma depresiboak eraginez. Adibidez, arratoietan burututako ikerketa batean, IFN- $\alpha$ administratuz, plasman IL-6-aren igoera bat ikusi zen, eta horretaz gain, portaeraren asaldura ere bai. Izan ere, behartutako igeriketaren azterketan (FST) denbora gehiago eman zuten mugitu gabe. Horrez gain, beste ikerketa 
batean, saguetan lipopolisakaridoa administratu zen eta depresioarekin loturiko sintoma somatiko eta psikomotorrak erakutsi zituzten, plasmako IFN- $\gamma$ eta TNF- $\alpha$ kontzentrazioak igotzeaz gain (8).

Azkenik, gizakietan eginiko zenbait ikerketak sistema immunea itu duten terapiek onura klinikoak izan ditzaketela adierazten dute. Adibidez, azido azetilsalizilikoa (antiinflamatorioa) fluoxetina antidepresiboarekin konbinazioan erabili zenean, depresioaren gutxitzearen portzentaje altuagoak agertu ziren, lehenago fluoxetina bakarrik erabilita erresistenteak ziren depresiodun pazienteetan baino. Terapia antiinflamatorioaren ekintza antidepresiboa gaixotasun autoimmunedun edo inflamatoriodun pazienteetan ere ikusi da. Esate baterako, psoriasidun gaixo talde bati TNF- $\alpha$-aren antagonista den etanercept ematean, plazeboa eman zitzaien beste gaixo talde batean baino hobekuntza handiagoa lortu zen, sintoma depresiboei dagokienez. Aurkikuntza horiek adierazten dute zitokinen antagonistek edo agente antiinflamatorioek immunoaktibazioak eragindako portaeraaldaketak blokeatzeko balio dezaketela (20).

\section{Depresioa eta neuroinflamazioa hurrenez hurren}

Nerbio-sistema zentralean hanturaren inguruan egin diren aurkikuntza guztiek hauondorioztatzera bultzatu gaituzte: sistema immunearen hiperaktibazioa eta horrekin erlazionatutako seinalizazio-jauzi guztiak, zitokina proinflamatorioen mailak igotzeaz gain, glukokortikoide eta sistema immunearen desorekarekin eta funtzio neuropsikiatriko kaltetuekin erlazionatuta egon daitezke. Izan ere, depresioa duten pertsonen LZRan IL-1 $\beta$, IL- 6 eta TNF- $\alpha$ zitokina proinflamatorioen mailak handituta daudela aurkitu da garuneko hainbat gunetan, hala nola hipokanpoan (8).

Teoria neuroinflamatorioak, hortaz, garunean zitokina proinflamatorioen bidez eragindako hantura dagoela proposatzen du. Horiek, itu ezberdinetan eraginez, hanturaren erantzun zentrala anplifikatuko lukete. Erantzun hori denboran zehar mantenduz gero, garunean atrofia sortuko luke eta zelulak eta neurogenesia kaltetu, zeina depresioaren kausetariko bat den (3. irudia).

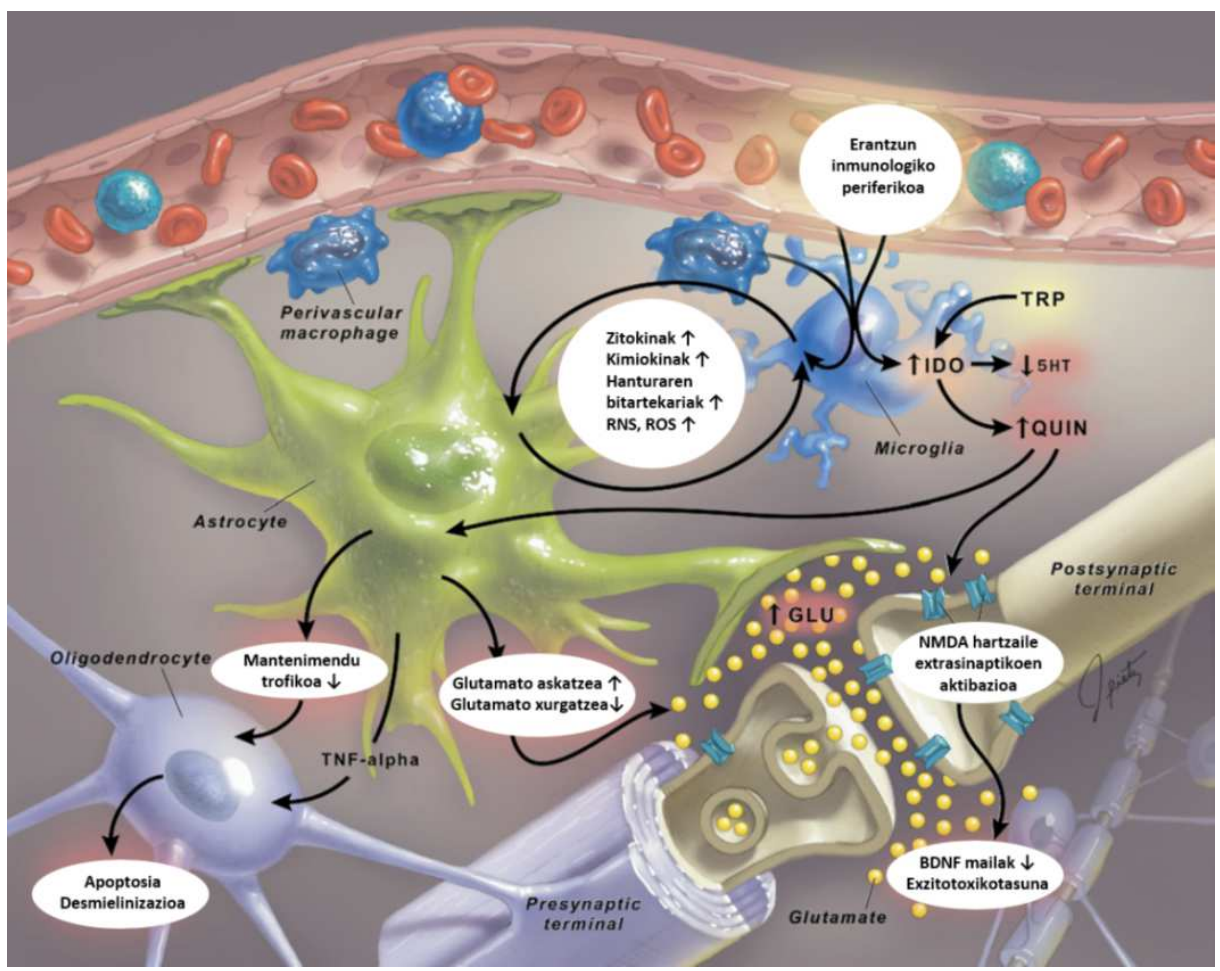

3.irudia. Teoria neuroinflamatorioaren arabera NSZ mailan gertatuko liratekeen prozesuen laburpena. Miller A, Maletic V eta Raison C. Inflammation and Its Discontents: The Role of Cytokines in the Pathophysiology of Major Depression. Biological Psychiatry. 2009;65(9):732-741. 
Animalietan eginiko azterketek periferiatik garuneranzko seinale inflamatorioen hainbat transmisiobide aurkitu dituzte, hala nola bide humorala (muga hematoentzefalikoa zeharkatuz), bide neurala (zitokinen lotura-nerbio aferenteen zuntzetara) edo bide zelularra (monozitoen lekualdaketa garun baskulatura). Gainera, gizakietan egindako aurkikuntzetako batek adierazi duenez, periferian erantzun inflamatorio eta immune bat ematen denean, TNF- $\alpha$-aren aktibazio akutuak garuneko zitokina proinflamatorioen mailak kronikoki igotzen ditu. Horretaz gain, beren buruaz beste egindako pertsona talde baten garunetan burututako analisiek frogatu dute makrofago peribaskular eta haien aktibazioarekin eta zelula immuneen lekualdatzearekin lotutako faktore inflamatorioen geneespresioa handituta dagoela. Datu hauek periferiako ehunetan ematen diren erantzun inflamatorioek hantura garunera bidera dezaketela eta, ondorioz, depresioa ager daitekeela dioen ideia indartzen dute $(8,19)$. Gainera, periferiatik iritsitako hantura-erantzunak mikrogliaren aktibazioa eragin dezake. Izan ere, garuneko zitokina proinflamatorioen iturri nagusia mikroglia da (20).

\section{Mikroglia al da neuronen hiltzailea?}

Mikroglia NSZko sistema immunea osatzen duen zelula glial mota bat da. Mikrogliako zelulak beste ehunetako makrofagoen gisa aritzen dira NSZan, fagozitatzeko gaitasuna dute eta funtzio nagusia nerbio-ehuneko edozein kalte edo infekzio antzeman eta konpontzeko beharrezko neurriak hartzea da. Izan ere, hantura bezalako kalteen eta infekzioen aurrean mikroglia aktibatu egiten da eta mehatxuei aurre egiten die, zitokinen askapenaren bidez, beste zelula batzuei deituz.

Beren buruaz beste egin duten depresiodun gaixoen post-mortem garunetan berezko erantzun immunearen osagai diren hantura-zitokinen espresioaren igoera aurkitu da. Gainera, depresiodun pazienteen garunetako hainbat gunetan, hipokanpoa, PFC eta hipotalamoa adibidez, mikrogliaren aktibazioa deskribatu da. Hori gutxi balitz, neuroirudi-teknikekin burututako azterketa batean, non translokazio-proteina (TSPO) markatu den (aktibatutako mikroglian, makrofagoetan eta astrozitoetan gainespresatzen dena), asaldura depresibo nagusia duten pertsonen garunetan mikrogliaren immunoaktibazio handiagoa dagoela aurkitu da. Ikerketa gehiagotan frogatu denez, periferiako estimulu immune indartsu baten aurrean, endotoxinaren administrazioa adibidez, boluntario osasuntsuen garuneko hainbat gunetan zelulen aktibazioa antzeman da markatutako TSPO ligandoen bitartez (19).

Bestalde, saguetan ere periferian induzitutako hanturak mikroglian eragin dezakeela frogatu da. Handitutako gibeletik askatutako TNFa mikrogliako zelulen kimiokina (zitokina mota bat) ekoizpena induzitzeko gai zela ikusi zen, monozitoak garunera erakartzea eragiten zuena. Beste azterketa batean, arratoiei IFN- $\alpha$ periferikoki administratu ondoren, IL-1 $\beta$-aren igoera deskribatu zen hipokanpoan, periferiako sistema immunearen estimulazioak gehiegizko erantzun neuroinflamatorioa eragin dezakeela adieraziz (8).

Neurotransmisioak umorearen eta emozioen erregulazioan duen garrantzia ezaguna denez, jakin-min handia piztu da hanturak eta zitokina proinflamatorioek monoaminen eta glutamato neurotransmisore kitzikatzailearen gain duten ekintzan.

\section{IDO entzimak utzitako urratsen atzetik}

Teoria neuroinflamatorioan garrantzia hartu du indolamina 2,3-dioxigenasa edo IDO entzimak. IDO mikrogliako zelulak bezalako zelula immunorregulatzaileek edo makrofago aktibatuek aktibatzen eta induzitzen dutela ikusi da. Triptofano aminoazidoaren (serotoninaren aitzindaria dena) degradazioa katalizatzen du eta hori kinurenina bihurtu. Kinurenina degradatzean, neurotoxikoa den azido kinolinikoa ( $\mathrm{N}$-metil-D-aspartato edo NMDA hartzaile glutamatergikoen agonista) sortzen da, baita beste bi metabolito ere, batek kalte oxidatiboa eragin dezakeelarik (8). 
Depresioan IDOaren aktibazio zentrala handitua dagoela proposatu da. Izan ere, zitokina proinflamatorioek (IFN- $\gamma$ eta TNF- $\alpha$, adibidez) oso erraz induzitu dezakete makrofagoetan edo mikroglian dagoen IDOa. Ikerketa batean, IFN- $\alpha$ terapia jaso bitartean depresioa pairatu zuten pazienteetan odol periferikoko triptofano-deplezioa zuzenean kinureninaren igoera esanguratsuekin erlazionatua zegoela antzeman zen. Emaitza horietan oinarrituz, deprimituen triptofano-mailen jaitsieraren erantzulea IDO aktibitatearen igoera izan zitekeela proposatu da (10). Bestetik, beren buruaz beste egin duten depresiodun pazienteen mikroglian azido kinolinikoaren kantitatea igota dagoela ikusi da (19).

Saguetan eginiko azterketa batean ere, lipopolisakaridoaren administrazioak periferiako eta NSZko IDO indukzioa eragiten duela ikusi da, baita garuneko serotoninaren metabolizatze handiagoa ere, hori guztia sintoma depresibo somatiko eta psikomotorrei lotua (8). Gainera, IDOaren blokeoak erakutsi du gai dela saguetan lipopolisakarido bidez induzitutako jarrera depresiboa inhibitzeko (20).

Hortaz, IDOa depresioarekin erlazionatu da, triptofanoaren erabilgarritasuna jaitsiz serotoninaren biosintesian eragiten duelako. Baina IDOaren aktibazioak eta kinureninaren sorrerak neurotransmisoreetan eta portaeran eragin gehiago dituztela ikusi da, serotoninarekin erlazio zuzenik ez dutenak. Aipatu bezala, kinureninaren metabolito toxikoa, azido kinolinikoa, mikroglian sortzen da eta eszitotoxizitatean eta kalte oxidatiboan lagunduko luke (20).

Astrozitoak nerbio-sistemako zelula glial nagusi eta ugarienak dira. Funtzio nagusia neuronen ongizatea mantentzea da, nutrienteen garraioa burutuz, mikroingurunea kontrolatuz, eta kalteren bat gertatuz gero, neuronen birsorkuntzan, hau da, neurogenesian, parte hartzen dute.

Depresiodun pazienteen garuneko hainbat gunetan, PFC eta hipotalamoa adibidez, astrozitoen aktibazioa deskribatu da (19). Gainera, astrozitoak gai dira mikroglia aktibatzeko, NSZko hanturaerantzuna areagotuz. Karraskarietan burututako azterketa batean astrozitoek jariatutako kimiozina batek, 1 proteina monozito kimioerakarleak (MCP-1), mikroglian eragin eta horrek zitokina proinflamatorioak jariatzea eragin zuen lipopolisakarido-administrazioaren ondoren (20).

Bestalde, azido kinolinikoak, mikrogliak jariatutako zitokinek eta oxigenoaren espezie erreaktiboek astrozitoetan kaltea eragiten dute, eta, ondorioz, haien funtzionamendua oztopatu. Aipatutako faktoreekiko gehiegizko esposizioak astrozitoek kontrolatzen duten glutamato neurotransmisore kitzikatzailearen askapena handitzen du, horren birxurgapena inhibitzearekin batera. Horretaz gain, NMDA hartzaileak aktibatzen ditu neuronetan, zuzenean. Hortaz, ingurunean erabilgarri dagoen glutamato kantitatea igota egongo litzateke neuronak hiperaktibatuz eta eszitotoxikotasuna eraginez (20).

Beste alde batetik, TNF- $\alpha$-k eta IL-1-ak astrozitoak eta mikroglia induzitzen dituztela ikusi da, oxigenoaren espezie erreaktiboak eta nitrogenoaren espezieak ekoitzieta askatzea eraginez. Gainera, azido kinolinikoak ere estres oxidatiboa eragiten du. Horien guztien aurrean sortzen den estres oxidatiboak neuronak kaltetuko lituzke, oso sentikorrak baitira kalte oxidatiboarekiko (20).

\section{Eszitotoxikotasuna depresioaren muinean...}

Esan bezala, azido kinolinikoak hartzaile glutamatergikoen aktibazioan eragindako igoera eta glutamatoa bera eszitotoxikotasunaren eragileak dira. Glutamatoa NMDA hartzaile estrasinaptikoei etengabe lotzean, horien hiperaktibazioa gertatzenda eta horren ondorioz gertatzen den heriotza neuronalari eszitotoxikotasuna deritzo.

Depresioan hartzaile glutamatergikoen aktibazioaren igoera gertatzen dela proposatu da. Hori frogatzen duten hainbat ikerketa burutu dira. Esaterako, IFN- $\alpha$ terapia jasotzen duten pazienteen garuneko gune batzuetan, gongoil basaletan adibidez (prozedura-ikasketarekin edo eguneroko portaerekin erlazionatuak), glutamato-mailen igoera deskribatu da eta igoera horren eta agertutako 
sintoma depresiboen artean korrelazioa dagoela ikusi da (19). Beste aurkikuntza batzuen arabera, CRP maila altuak (hanturaren markatzaile goiztiarra dena) dituzten depresiodun gaixoek glutamatomaila altuak dituzte garunean. Emaitza horiek, gainera, korrelazioa erakutsi dute anhedonia eta geldotasun psikomotorra bezalako sintoma depresiboekin. Horretaz gain, hartzaile glutamatergikoak edo IDOaren aktibitatea saguetan blokeatzeak lipopolisakaridoaren bidez induzitutako portaera depresiboa ez agertzea eragin du, baina horrek ez du eraginik izan erantzun inflamatorioan. Horren arabera, glutamato eta azido kinolinikoaren handitzeak eragindako hartzaile glutamatergikoen gainaktibazioa hanturak portaera depresiboa eragiteko izan dezakeen mekanismo bat izan liteke (19).

Depresioaren teoria neuroinflamatorioaren arabera esan bezala, berezko erantzun immunearen zitokinak periferiatik iristen diren momentutik aurrera NSZan hantura-prozesua piztu eta etengabe indartzen joango litzateke, hainbat mekanismo eta kalteren bitartez (3.irudia): glutamatoaren erregulazioan gertatutako asaldurak, azido kinolinikoaren bidezko NMDA hartzaileen aktibazioa, neurotransmisio glutamatergikoaren gainaktibazioa, kalteak oligodendrozitoetan...Oligodendrozitoak neuronak inguratzen dituzten mielina-sareak ekoizten dituzten zelula glialak dira eta NSZan gertatzen den hantura-jauziarekiko bereziki sentikorrak dira. TNF- $\alpha$ bezalako zitokina proinflamatorioen gehiegizko eraginak zelula horiengan efektu toxiko zuzena duela ikusi da,neuronak eta zelulak apoptosira eta desmielinizaziora bideratuz (20). Guztira eragingo liratekeen kalteek garuneko sostengu neurotrofikoaren murrizpenean bukatuko lukete. Gainera, eszitotoxikotasunak eta haren ondorioz sortutako erradikal aske eta estres oxidatiboak, apoptosi bidez, plastikotasun neuronala etetea lortuko lukete (20).

BDNFa neurogenesia eta neuroplastikotasuna (neuronen arteko komunikazio egokia ziurtatzen duen ezaugarria) bultzatzen dituen faktore neurotrofikoa da. Depresioan garrantzia hartu duen faktore neurotrofikoa da, gaixotasun neurologikoekin erlazionatutako hainbat aurkikuntza egin direlako. Esate baterako, eszitotoxikotasuna sortzeaz gain, gehiegizko glutamato-mailen bidezko NMDA hartzaileen aktibazioak BDNFarenekoizpena jaistea eragin dezakeela ikusi da (20).

Bestalde, hanturak ere hipokanpoko BDNFari eragiten diola ikusi da, baita neurogenesiari eta dendriten arborizazioari ere, ikasteko ahalmenean eta oroimenean arazoak eraginez. Aipatzekoa da farmako antidepresiboen ekintza monoaminen erabilgarritasun sinaptikoa igoaz eta BDNFa induzituaz, hau da, neurogenesia bultzatuz burutzen dutela. Bestalde, depresioaren animaliaereduetan IL-1 $\beta$-a eta TNF- $\alpha$-a BDNFaren kontzentrazioa jaisteko gai direla ikusi da. BDNFaren kontzentrazioaren handitzea erantzun antidepresiboa agertzeko beharrezko baldintza izango litzateke. Beraz, IL-1 $\beta$ eta TNF- $\alpha$ bezalako zitokina pronflamatorioak areagotzeak ekintza antidepresiboa ahultzen duela ikusi da, monoaminen erabilgarritasun sinaptikoa jaisteaz gain, BDNF mailak jaitsi eta glutamato-mailak igotzen dituztelako. Ondorioz, zitokinek eragindako efektu hauek azal dezaketeare agotutako hantura duten eta tratamendu antidepresibopean dauden pazienteen tratamenduaren arrakasta falta. Izan ere, tratamendu antidepresiboarekiko erresistenteak diren pazienteetan handitutako hanturaren markatzaileen kontzentrazioak antzeman dira (19).

Zitokinek eta beste immunomodulatzaile batzuek garrantzi handia dute garunaren garapen goiztiarrean, baita helduen plastikotasun neuronalean ere. Baina zitokina proinflamatorioen aurreko agerpen luzeak plastikotasun neuronal horikaltetu eta depresioaren agerpenean lagundu dezake. TNF- $\alpha$ eta IL-1 $\beta$ maila patologikoek plastikotasun neuronala kaltetzen dutela erakutsi dute. Laburbilduz, gero eta datu gehiagoren arabera, zitokina zentralek berebiziko garrantzia dute neuronen plastikotasun eta biziraupenean. Estresaren, gaixotasunen edo substantzia/botiken erabileraren ondoriozko zitokinen orekaren galeraren kalte kronikoak iraupen luzeko aldaketak dakartza garunaren anatomian eta funtzionamenduan, eta kalteok umorean, kognizioan edo portaeran eragin zuzena izango dute (8).

\section{Ondorioak: tratamendu berrien bila}

Depresioa gaixotasun multifaktoriala den heinean, atzetik hainbat kausa eta faktore daude, koadro sintomatiko ezberdinak agertzea eragiten dutenak. Hortaz, gaitz mental hau eragiten duten 
mekanismoak ulertzea ezinbestekoa da tratamendu eraginkorra ezarri ahal izateko. Neuroimmunologian eginiko ikerkuntzak informazio ugari eman du, bereziki HPA ardatzaren aktibitatearen, hanturaren eta immunitatearen inguruan.

Lortutako emaitza kliniko eta preklinikoek honako hipotesi hau indartzen dute: hanturak eta immunitatearen desorekak neurotransmisoreen metabolismoan, funtzio neuroendokrinoan, plastikotasun sinaptikoan eta faktore neurotrofikoen ekoizpenean eragin dezaketela proposatzen duen hipotesia. Hori horrela izanik, garun inflamatuan zirkuitu neuralak kaltetzea eta sintoma depresiboak agertzea erraztuko litzateke.

Aurrekoa kontuan izanik, depresioaren inguruan ezagutzen dugunaren zenbait hutsune betetzea beharrezkoa da oraindik. Hasteko, tresna hobeak behar ditugu depresioa diagnostikatu eta tratatzeko. Tresna horien artean odol biomarkatzaileak egon litezke. Horien bidez, prozesu fisiopatologiko espezifikodun pazienteak identifikatu ahalko lirateke eta, gainera, depresioarentzako bide garrantzitsuetan emandako erantzun terapeutikoa monitorizatzeko erabilgarriak izango lirateke. Hortaz, biomarkatzaile periferikoak, kasu honetan, TNF- $\alpha$, CRP edo IL- 6 bezalako zitokina proinflamatorioak, depresioaren tratamendua pertsonalizatzeko baliagarriak izan daitezke, betiere hantura ageri duten pazienteetan. Horren harira, beharrezkoa da depresioaren definizio berri bat egitea, non profil sintomatikoak eta neurobiologia hobeto erlazionatuko liratekeen. Izan ere, estrategia terapeutiko ezberdinak beharrezkoak izan daitezke sintoma depresiboak eragiten dituzten mekanismo fisiopatologikoen arabera. Amaitzeko, sintoma depresiboen eta markatzaile periferiko inflamatorioen arteko erlazioari buruz gehiago ezagutzeko ikertzen jarraitu behar da. Horretarako depresioaren animalia-ereduak hobetzea ezinbestekoa da depresioa hobeto ezagutzeko orduan.

Orain arte lortutako datuen arabera, hantura eta erantzun immunea itu bezala dituzten tratamenduen potentzial terapeutikoa ezagutzea garrantzitsua izan daiteke depresioaren tratamendurako. Hainbat entsegu klinikotan lortutako emaitzek COX2 inhibitzaileek antidepresiboen efektu terapeutikoetan eragin sinergikoa dutela frogatu da. Celecoxib-ez gain, beste antiinflamatorio batzuek ere eragin antidepresiboak izan dituzte beren eragin antiinflamatorioekin batera. Esate baterako, minoziklina antibiotikoak mikroglia aktibatuak ekoitzitako zitokina proinflamatorioak askatzea murrizten du. Horri esker, minoziklinak antiinflamatorio-profila izateaz gain eragin antidepresiboak sortzen dituela frogatu da. Emaitza hauek depresioaren tratamenduan eraginkorrak izan daitezkeen itu farmakologiko berriak jarri dituzte ikusgai, epe motzera tratamendua hobetzen lagunduko dutenak.

\section{Erreferentzia bibliografikoak}

1 La depresión [Internet]. Ginebra: Organización Mundial de la Salud; 2016 [Kontsulta: 201803-27]. 2 or. Eskuragarri: http://www.who.int/mediacentre/factsheets/fs369/es/

2 López-Muñoz F, Álamo González C. Neurobiology of depression. Boca Raton, FL: Taylor \& Francis; 2012.

3 Horrillo Furundarena I. Regulación del sistema noradrenérgico central tras modulación farmacológica del eje hipotalámico-hipofisiario-adrenal. Efecto del tratamiento antidepresivo [Doktorego-tesia]. [Bilbo]: UPV-EHU; 2011. 63-115.

4 Horrillo Furundarena I. Depresio nagusia. Donostia: Farmazialari Euskaldunen Elkartea; 2006.

5 Belmaker RH, Agam G. Major depressive disorder. N Engl J Med. 2008; 358(1):55-68.

6 Syvälahti E. Monoaminergic mechanisms in affective disorders. Med Biol 1987; 65(2-3):89-96.

7 Sterner EY, Kalynchuk LE. Behavioral and neurobiological consequences of prolonged glucocorticoid exposure in rats: relevance to depression. Prog Neuropsychopharmacol Biol Psychiatry. 2010; 34(5):777-90.

8 Loftis JM, Huckans M, Morasco BJ. Neuroimmune mechanisms of cytokine-induced depression: current theories and novel treatment strategies. Neurobiol Dis. 2010; 37(3):51933. 
9 Martínez Sanchis S, Almela Zamorano M. Hormonas, estado de ánimo y función cognitiva. Las Rozas, Madrid: Delta Publicaciones; 2007.

10 Irwin MR, Miller AH. Depressive disorders and immunity: 20 years of progress and discovery. Brain Behav Immun. 2007; 21(4):374-83.

11 Pariante CM, Lightman SL. The HPA axis in major depression: classical theories and new developments. Trends Neurosci. 2008; 31(9):464-8.

12 Pariante $\mathrm{CM}$, Miller AH. Glucocorticoid receptors in major depression: relevance to pathophysiology and treatment. Biol Psychiatry. 2001; 49(5):391-404.

13 McQuade R, Young AH. Future therapeutic targets in mood disorders: the glucocorticoid receptor. Br J Psychiatry. 2000; 177:390-5.

14 Adzic M, Djordjevic J, Djordjevic A, Niciforovic A, Demonacos C, Radojcic M, Krstic-Demonacos M. Acute or chronic stress induce cell compartment-specific phosphorylation of glucocorticoid receptor and alter its transcriptional activity in Wistar rat brain. J Endocrinol. 2009;202(1):87-97.

15 Nemeroff CB, Widerlöv E, Bissette G, Walléus H, Karlsson I, Eklund K, Kilts CD, Loosen PT, Vale W. Elevated concentrations of CSF corticotropin-releasing factor-like immunoreactivity in depressed patients. Science. 1984;226(4680):1342-4.

16 Furtado $M$, Katzman MA. Examining the role of neuroinflammation in major depression. sychiatry Res. 2015; 229(1-2):27-36.

17 McKay MS, Zakzanis KK. The impact of treatment on HPA axis activity in unipolar major depression. J Psychiatr Res. 2010; 44(3):183-92.

18 Grenón S, Mereles BL, Salvi BE, Payes M, Benitez J. Citocinas y Quimiocinas [Internet]. Posadas: Universidad de Misiones; 2014 [Kontsulta: 2018-03-27]. 42 or. Eskuragarri: http://docplayer.es/31511037-Citocinas-y-quimiocinas.html

19 Miller AH, Raison CL. The role of inflammation in depression: from evolutionary imperative to modern treatment target. Nat Rev Immunol. 2016; 16(1):22-34.

20 Miller AH, Maletic V, Raison CL. Inflammation and its discontents: the role of cytokines in the pathophysiology of major depression. Biol Psychiatry. 2009; 65(9):732-41.

21 Bonaccorso S, Marino V, Biondi M, Grimaldi F, Ippoliti F, Maes M. Depression induced by treatment with interferon-alpha in patients affected by hepatitis $C$ virus. J Affect Disord. 2002; 72(3):237-41.

22 Capuron L, Raison CL, Musselman DL, Lawson DH, Nemeroff CB, Miller AH. Association of exaggerated HPA axis response to the initial injection of interferon-alpha with development of depression during interferon-alpha therapy. Am J Psychiatry. 2003; 160(7):1342-5.

23 Besedovsky HO, del Rey A. Immune-neuro-endocrine interactions: facts and hypotheses. Endocr Rev. 1996; 17(1):64-102.

24 Leonard BE. Inflammation and depression: a causal or coincidental link to the pathophysiology? Acta Neuropsychiatr. 2018;30(1):1-16. 